\title{
THE INTERNAL AUDITORS OF PHARMACEUTICAL QUALITY SYSTEMS COMPETENCE IMPROVING
}

\author{
Viacheslav Lebedynets \\ Department of management, economy and quality assurance in pharmacy ${ }^{l}$ \\ Tetiana Karamavrova \\ Department of management, economy and quality assurance in pharmacy ${ }^{I}$ \\ karamavrova.qms@gmail.com \\ ${ }^{I}$ National University of Pharmacy \\ 53 Pushkinska str., Kharkiv, Ukraine, 61002
}

\begin{abstract}
The importance of internal audits for the pharmaceutical company, which is indicated in the guidelines for good practices in pharmacy (in particular, GMP, GDP).

The issue of selection, training, grading, certification and continuous improvement of the auditor's competence at pharmaceutical companies are relevant and important both for domestic ones, and for foreign enterprises.

The aim of the study was to determine the competence of the pharmacy quality system internal auditors' and the areas of its development.

Materials and methods. The object of the study was the competence of internal auditors of pharmaceutical quality systems. Empirical and theoretical research methods were used, in particular the method of comparative analysis of scientific literature in the field of research, the method of structural and logical modeling. The information basis was the provisions of regulations and materials published in the open professional scientific literature.

Results. The competence of quality management system auditors in general and pharmaceutical quality system in particular consists of personal qualities, professional knowledge and skills. The ISO 19011 standard highlights the importance of evaluating and continuous development of auditors' competence. Such an assessment should take into account the needs of the audit program and its objectives. Areas of development of auditors' competence should be determined by the specifics of industry activities. This provision of the standard should be considered relevant for pharmaceutical companies.

Conclusions. We studied the requirements for the competence of QMS internal auditors of international and industry standards. A review of the regulatory framework showed a lack of information on the chosen area of the research. Defined requirements for the competence of the PQM audits staff assists the selection of specialists to the audit team so that the overall competence of the audit team is sufficient to achieve the objectives of the audit.

Keywords: internal audit, auditor, quality management system, pharmaceutical quality system, ISO 9001, ISO 19011, pharmaceutical company, auditor competence.
\end{abstract}

DOI: $10.21303 / 2504-5679.2021 .001625$

\section{Introduction}

The conduct of internal audits (IA) of pharmaceutical quality system (PQS) in Ukraine is regulated by a number of regulations, in particular, the Resolution of the Cabinet of Ministers of Ukraine № 929 of November 30, 2016 «On approval of licensing conditions for business activities for the production of medicines, wholesale and retail trade in medicines» (licensing conditions, LC) [1], Guidelines CT-H MOH of Ukraine 42-4.0:2020 «Medicines. Good manufacturing practice» (GMP Guidelines) [2], Guidelines CT-H MOH of Ukraine 42-4.3:2011 «Medicines. Pharmaceutical quality system (ICH Q10)» [3].

GMP Guidelines, LC regulate the availability of competent and qualified personnel to carry out all activities [1, 2]. In particular, such requirements apply to the IA process. Given that effective IA provides an opportunity to assess the functioning of a particular process, or PQS as a whole, they are of significant value to the management of the Pharmaceutical Company (PhC) [3].

Requirements for mandatory audits are also set out in the standard ISO 9001:2015 «Quality Management Systems. Requirements» (paragraph 9.2) and general recommendations for audits of management systems are given in the standard ISO 19011:2018 [4, 5]. 
The professional title of the position «Quality Systems Auditor» is provided under the National Classification of Ukraine «Occupational Classification» SC 003:2010 (here and further on the text «Classifier», occupation code number 2411.2). The classifier determines the qualifications of a specialist required to perform professional duties. Qualification requires professional competence [6].

At the same time, the term «professional competence» should be understood not only as knowledge of the requirements of relevant guidelines and standards (GxP Guidelines, ICH Q10, ISO 9001, etc.), but also a certain set of personal qualities and existing skills that allow audits at high professional level. Competence is a proven ability to apply knowledge and skills [6].

Our sociological research at some Ukrainian PhC showed that the lack of competence of auditors is one of the main reasons that cause problems with the IA effectiveness [6, 7].

At the same time, in Ukrainian education institution does not train such specialists in any field, including the pharmaceutical field of health care. Some higher education institutions train auditors in the framework of other industry specialties [8].

Currently, the demand of the pharmaceutical industry for such specialists far exceeds the capabilities of educational institutions. For these reasons, companies themselves organize training and grading of their auditors. Rarely a companies invites outside experts for training and education of auditors. Such activities lead to the lack of the standard approaches to the training of auditors and sustainable methods of assessing their competence. In turn, this leads to significantly different levels of professionalism of the audits themselves.

The issue of providing pharmaceutical competence at the stage of higher education has been studied by many authors $[9,10,11]$. In particular, the competencies of $\mathrm{PhC}$ staff were investigated and defined in the works $[12,13,14]$. Also, in the works the functional modular-competence model of the quality assurance specialist for $\mathrm{PhC}$ was covered, and also the curriculum of preparation of such specialists was substantiated and developed [15].

Most studies indicate that the importance of competence in all its meanings and aspects most deeply reflects the current state of the industry. Introduction of remote technologies of interaction between market participants, the use of which is now growing rapidly in all European countries and in Ukraine. It is the provision of competence of $\mathrm{PhC}$ specialists and their continuous development that allows enterprises to be competitive.

Although the researchers raised the issue of the competence of the PhC staff, we could not find works dedicated to determining the determination of the competence of the PhC's internal auditors.

The aim of the study was to determine the competence of the QMS internal auditors' and the areas of its development.

\section{Materials and methods}

The object of the study was the competence of internal auditors of QMS. Empirical and theoretical research methods were used, in particular the method of comparative analysis of scientific literature in the field of research, the method of structural and logical modeling. The information basis was the provisions of regulations and materials published in the open professional scientific literature.

\section{Results}

In our previous research, we have emphasized that performance indicators of the IA process should characterize the value of audit reports to management. First of all, such criteria should characterize the value of the audit reports for the management, which is based on the decision to optimize the company. It is connected with an important role of audits in maintaining the functioning and development of QMS [8].

The value of the reports can be evaluated by expert method using relevant questionnaires with certain rating scales. Such an assessment should be carried out after each auditor, under certain conditions, at the end of the audit program [8].

We propose to evaluate the effectiveness of IA using questionnaires/evaluation forms, covering the following indicators:

- timely information;

- availability of information presentation; 
- usefulness of information provided by auditors to senior management;

- existence of evidence of the submitted information and others.

It is the competence of auditors determines the ability to assess the level of functioning of the QMS, certain processes of the PhC or certain products.

In determining the competence of auditors, it is necessary to take into account audit criteria. There is a connection between the ability to apply knowledge and skills to achieve audit objectives. Thus, clearly defined audit criteria will make it possible to appoint appropriate competent specialists for the role of auditors in the audit team, so that the group has all the necessary knowledge and skills for a particular IA.

According to ISO 19011, auditors must adhere to certain principles that are consistent with the personal qualities of the auditors and help make the audit a reliable means of maintaining management policy. Adherence to ethical standards, honesty in the presentation of results, due diligence, confidentiality, independence, evidence-based approach - adherence to these principles is a prerequisite for ensuring reliable and reproducible audit findings, and ensuring a high probability that auditors, working independently of each other, will draw similar conclusions under similar circumstances $[5,6,8]$.

In previous studies, we proposed to divide the competence of the auditor into three components:

- professional knowledge (general and specialized),

- skills and abilities,

- personal qualities.

The principles described above are implemented in the presence of certain personal qualities, which we described in detail in the previous stages of the study [6].

Professional knowledge and skills are divided into: specialized knowledge of Quality Management (and the pharmaceutical industry in particular), and general knowledge and skills in the organization and conduct of IA.

Specialized knowledge can be defined as the requirements for the auditor qualification. In practice, qualifications are assessed by indicators:

- basic education,

- practical experience,

- training.

The criteria are shown in Table 1.

Table 1

Indicators and criteria for the component competence of auditors

Qualification requirements for internal auditors of QMS

\begin{tabular}{ll}
\hline \multicolumn{1}{c}{ Indicators } & \multicolumn{1}{c}{ Criteria } \\
\hline Basic education & $\begin{array}{l}\text { Higher pharmaceutical, technical or economic education; education of a specific type and subject area, } \\
\text { which contribute to the development of specialized competence. }\end{array}$ \\
Practical experience & $\begin{array}{l}\text { Experience in the quality field - not less than } 3 \text { years } \\
\text { Professional training }\end{array}$ \\
$\begin{array}{l}\text { Professional education by the educational program «Quality, certification and standardization» (or simi- } \\
\text { lar) and training in the training program of QMS auditors }\end{array}$
\end{tabular}

General audit training should ensure the acquisition of up-to-date knowledge of audit practice. In turn, a well-trained auditor must possess and apply the necessary methods, know the principles and have the organizational skills to conduct the IA. In particular, auditors need to know and be able to:

- develop an audit program taking into account the objectives of quality management system;

- analyze and determine the criteria for the audited entity;

- identify and minimize the risks associated with the audit program and the IA process;

- develop a plan on-site audit;

- feed audit issues, make up and keep records in the checklist;

- communicate with employees (site, unit, process) within the audit object; 
- analyze and evaluate the characteristics and performance indicators of the audit object, in order to identify evidence and generate audit data;

- objectively assess the information, situations observed during audits;

- make meaningful notes during the audit;

- formulate non-compliance reports and initiate CAPA development;

- compile protocols and reports by the IA results, etc [3, 5].

For the chief auditor, in addition to outstanding skills, one of the additional required skills is to evaluate the implementation of the audit program according to pre-established indicators.

We have summarized the main indicators of professional knowledge and skills of auditors in 10 main blocks (Fig. 1). These blocks contain indicators related to general knowledge and skills of auditing, specialized knowledge in the field of QMS, and indicators of social and communicative abilities.

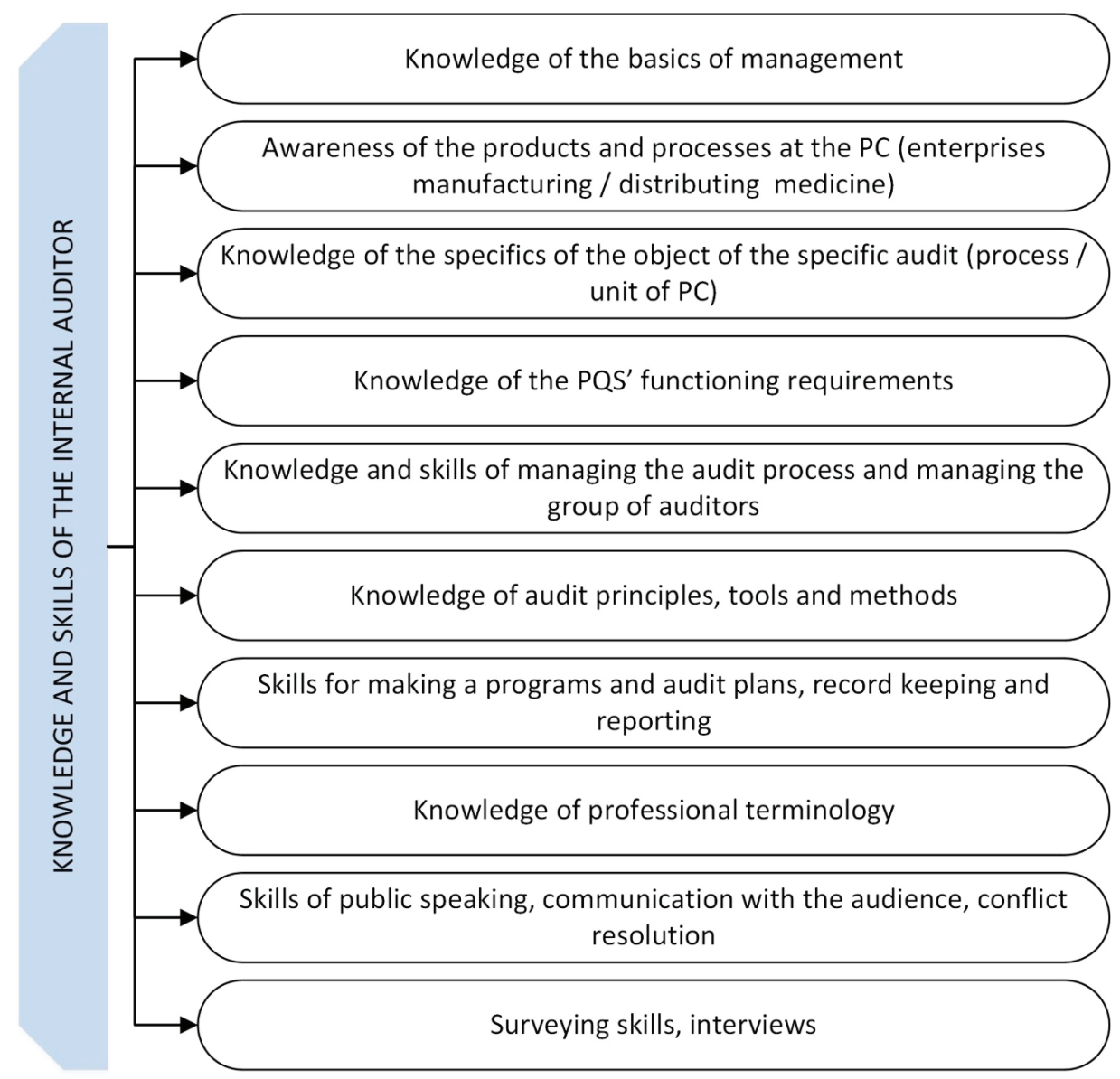

Fig. 1. Categories of knowledge and skills of internal auditors of the pharmaceutical quality system

The 10 blocks of QMS auditors' competence may include, but are not limited to:

- management knowledge. Relevant knowledge provides an understanding of the organization management principles, taking into account its size, ownership, organizational structure, existing information system, data storage, systems of document circulation, information technologies. It also includes knowledge of legal requirements applicable to PhC. There is also a need for awareness of the division of responsibilities and authority, reporting, evaluation of the quality of work performed by the object of audit, etc.;

- awareness of the products and processes of $\mathrm{PhC}$ (enterprises producing or distributing medicines). It is assumed that there is knowledge about products and processes in the operation at 
the $\mathrm{PhC}$, sufficient for a full understanding by the group members of applicable criteria of a specific audit (standard, guidelines or other normative documents);

- knowledge of the specifics audit object (the object is usually a process or organization unit of $\mathrm{PhC}$ ). This information about the type of products or features of a specific $\mathrm{PhC}$ process is needed for accurately determination of the audit terms, audit plan preparation, questionnaires (check-lists) and other accompanying audit documents;

- knowledge of the PQS' functioning requirements. Knowledge of Good Practice Guidance (GMP/GDP) requirements and other regulatory documents that $\mathrm{PhC}$ is govern. Knowledge should be sufficient to determine the state of functioning of the PQM and its compliance with established requirements;

- knowledge and skills of the audit process managing and managing of the auditors group. Ability to manage the audit process to achieve the established audit objectives within agreed timeframes. This knowledge is needed for the head of the audit team who should hold meetings professionally, to ensure the effective exchange of information between members of the group and the subject of audit, to assign tasks and to modify them as necessary, to apply moderation principles and to monitor the dynamics of group processes, to be able to effectively resolve disputes, to prove the need for certain decisions of the audit team, to balance the strengths and weaknesses of the individual members of the audit team;

- knowledge of the audit principles, appropriate means and methods. Knowledge of the basic principles, practices and techniques of conducting audits in a sufficient amount for the realization and objective assessment of the audit activity;

- skills for making a programs and audit plans, record keeping and reporting. Ability to develop supporting documentation, quickly registers information, create records and compile reports on the results and conclusions of the audit;

- knowledge of professional terminology. Ability to effectively communicate with employees of different positions at any level of the organization, using appropriate profile terminology, expressions and professional language;

- skills of public speaking, communication with the audience, conflict resolution, etc., including the ability to clearly present the results and conclusions of the audit. It is especially important for the head of the audit team to present the relevant audit findings, conclusions and recommendations (for example, at the final meeting);

- surveying skills, interviews. Ability to receive relevant information during an interview with representatives of the audit object, asking well-formulated questions, understands and evaluates responses [7].

The competence of internal auditors can be acquired and improved by evaluating professional trainings, seminars, both for pharmaceutical areas and for auditing. This area of professional development should also include the acquisition of additional education in a particular field. For example, for auditors who evaluate the functioning of pharmaceutical laboratories, will be advisable to have an education in pharmacy, clinical pharmacy, biopharmacy, chemistry etc.

Given that the functions of internal auditors are usually performed by employees in key positions, it will be appropriate to form groups of auditors so that $\mathrm{PhC}$ employees in appropriate technical, managerial or professional positions have the opportunity to share their experience. Such experiences include self-assessment, decision-making, planning, delegation, problem-solving, and communication with management, professionals, colleagues, customers and other stakeholders.

It is considered good practice to conduct audits of other management systems. Such audits can be external audits of suppliers, partners. Or even invite experts from other $\mathrm{PhC}$ to conduct IA of your company. It should be discussed in advance that such audits are not conducted in order to find non-conformities to destroy partners' image, but to share experiences and find potential directions for the QMS development. In the case of big PhC with a large number of branches, it is common practice to send auditors from one branch to another, as each branch may have its own specifics. Such branching of branches is inherent in distributive $\mathrm{PhC}$, where one of the branches may specialize in medicine that require specific storage and control requirement, the other branch the circulation of medicine for general use and food supplements. 
Acquisition of competence on the principle of «exchange of experience» should be acquired under the supervision of an auditor who competent in the same specialization. Accordingly, in order to develop the competence of the chief auditor/head of the audit team, it is necessary to perform duties under the guidance and supervision of another auditor who has the competence of the audit team head.

We would like to add that additional internships in certification bodies will also contribute to the development of general competence.

Study limitations. The described research was carried out as one of the stages within the project of creating an educational and methodological complex for the internal audit process of PhC.

Further research will be directed at developing a training program for PQS, diagnostic tools of their competence, determine and development of personal qualities.

\section{Conclusions}

The ability to achieve the objectives of the IA depends on the trust in the auditors and their competence. Personnel involved in the planning and conduct of IA on PhC, must have a sufficient level of knowledge and skills, personal qualities that will help solve the tasks to achieve the goal of IA. Also, a sufficient level of developed competence of the auditor provides an opportunity to solve problems of various kinds during the audit at the site, to effectively assess changes and predict probable risks.

Internal auditors must constantly improve their competence. This can be achieved in several ways, such as gaining additional work experience, training, internships, attending seminars and more. When choosing the direction of competence development, it is necessary to take into account current trends in the development of the pharmaceutical industry.

\section{References}

[1] Pro zatverdzhennia Litsenziinykh umov provadzhennia hospodarskoi diialnosti z vyrobnytstva likarskykh zasobiv, optovoi ta rozdribnoi torhivli likarskymy zasobamy, importu likarskykh zasobiv (krim aktyvnykh farmatsevtychnykh inhrediientiv) (2016). Postanova KMU No. 929. 30.11.2016. Available at: https://zakon.rada.gov.ua/laws/show/929-2016- \%D0 \%BF\#Text

[2] Likarski zasoby. Nalezhna vyrobnycha praktyka: ST-N MOZU 42-4.0:2020 (2020). Kyiv: MOZ Ukrainy, 356.

[3] ICH Q10 Pharmaceutical Quality System. European Medicines Agency (2008). Amsterdam. Available at: https://www.ema. europa.eu/en/ich-q10-pharmaceutical-quality-system

[4] Systemy upravlinnia yakistiu. Vymohy (ISO 9001:2015, IDT): DSTU ISO 9001:2015 (2016). Kyiv: DP «UkrNDNTs», 22.

[5] ISO 19011:2018 Guidelines for auditing management systems (2018). ISO/FDIS 19011:2018 Supporting technologies. Available at: https://www.iso.org/obp/ui/\#iso:std:iso:19011:ed-3:v1:en

[6] Karamavrova, T. V., Lebedynets, V. O., Plyaka, L. V. (2018). Determination of the approaches to estimation of personal qualities of auditors of the pharmaceutical quality systems. Social Pharmacy in Health Care, 4 (3), 33-41. doi: http://doi.org/ 10.24959/sphhcj.18.119

[7] Karamavrova, T. V., Lebedynets, V. O. (2018). Determination of audit group members' competence at pharmaceutical enterprises. Topical issues of new drugs development. Kharkiv: NUPh, 406-407.

[8] Lebedynets, V. O., Karamavrova, T. V. (2018). Some aspects of performance evaluation and motivating of internal auditors of pharmaceutical companies' quality management systems. Upravlinna, ekonomika ta zabezpecenna akosti v farmacii, 4 (56), 11-16.

[9] Koniashyna, I. B. (2017). Development of professional competence of prospective specialists pharmaceutists. Innovative Solutions in Modern Scienc, 9 (18), 65-74. doi: http://doi.org/10.26886/2414-634X.9(18)2017.5

[10] Hirvonen, J., Salminen, O., Vuorensola, K., Katajavuori, N., Huhtala, H., Atkinson, J. (2019). Pharmacy Practice and Education in Finland. Pharmacy, 7 (1), 21. doi: http://doi.org/10.3390/pharmacy7010021

[11] Sholoiko, N. (2019). Organizational and management competence in the structure of professional competence of future pharmacists. The sources of pedagogical skills, 24, 244-239. doi: http://doi.org/10.33989/2075-146x.2019.24.194901

[12] Kennedy, M.-C., Reast, A., Morrow, K., Bourke, F., Murphy, C., Arnett, R., Bradley, C. (2019). Reviewing Competence in Practice: Reform of Continuing Professional Development for Irish Pharmacists. Pharmacy, 7 (2), 72. doi: http://doi.org/ 10.3390/pharmacy7020072

[13] Nahornyi, V. V., Murzina, O. A., Nahorna, N. O., Kaplaushenko, T. M. (2018). Formuvannia profesiinykh kompetentsii fakhivtsiv farmatsevtychnoho profiliu. Perspectives of science and education. New York: SlovolWord, 116-127. 
[14] Kankaew, K. (2020). The Competencies-Based Development in Pharmaceutical Industry. Systematic Reviews in Pharmacy, 11 (12), 962-963.

[15] Gorodetskaia, V. I., Lebedinets, V. A., Kovalenko, S. N. (2013). Opredelenie professionalnykh kompetentnostnykh kharakteristik spetsialistov po menedzhmentu kachestva $\mathrm{v}$ farmatsii. Aktualnye voprosy obrazovaniia, nauki i proizvodstva v farmatsii. Tashkent: Tashkentskii farmatsevticheskii institut, 281-283.

[16] Yurkovska, L. H., Ubohov, S. H., Krasnov, V. V. (2020). Kontseptualni osnovy pravovykh ta etychnykh kompetentnostei shchodo upravlinnia yakistiu v farmatsii. Upravlinnia yakistiu v farmatsii. Kharkiv: NFaU, 199-201.

[17] Moracanin, V. (2012). Competence education and training for quality. Total Quality Management and Six Sigma. InTech, 197-216. doi: http://doi.org/10.5772/46105

[18] Ugarak, J., Korčok, D., Vuksanović, D. (2015). The Effectiveness of Internal Audits and Their Impact on System Improvement. International Journal of Scientific and Research Publications, 5 (4), 1-6.

[19] Waghmare, Y., Mahaparale, S. (2017). A review article on self inspection and quality audit. European journal of pharmaceutical and medical research, 4 (7), 358-364.

[20] Kannan, S., Morais, S. R., Prema, S., Chitra, K (2020). Auditing as A Management Tool in Pharmaceutical Companies. International Journal of Pharmacy and Biological Sciences, 10 (1), 230-235.

[21] Ul-Hameed, W., Mohammad, H., Shahar, H., Aljumah, A., Azizan, S. (2019). The effect of integration between audit and leadership on supply chain performance: Evidence from UK based supply chain companies. Uncertain Supply Chain Management, 7 (2), 311-328.

[22] Marinkovic, V., Heine, I., Milosevic Georgiev, A., Schmitt, R. H. (2020). Critical Incidents of Outsourcing Processes in Pharmaceutical Supply Chain: A Mixed-Methods Approach. Journal of Industrial Engineering and Management, 13 (3), $495-513$. doi: http://doi.org/10.3926/jiem.3085

Received date

Accepted date

Published date 29.01.2021
(C) The Author(s) 2021

This is an open access article under the CC BY license (http://creativecommons.org/licenses/by/4.0). 